\title{
Constraints Faced and Suggestions Offered by Women Self-Help Groups of Ahmedabad District, Gujarat in Carryout the SHG Activities
}

\author{
N. D. Chethan Patil ${ }^{1 *}$, J. K. Patel ${ }^{2}$, Naveen Kumar Gattupalli ${ }^{3}$, \\ Rahul Dundesh Bellagi ${ }^{1}$ and G. Manunayaka \\ ${ }^{1}$ ICAR-National Dairy Research Institute (NDRI), Karnal- 132001 (Haryana), India \\ ${ }^{2}$ KVK Arnej, Gujarat, India \\ ${ }^{3}$ B. A. College of Agriculture, AAU, Anand, Gujarat, India \\ *Corresponding author
}

\section{A B S T R A C T}

\section{Keywords}

Self-help group,

Empowerment,

Constraints,

Suggestion

Article Info

Accepted:

28 April 2020

Available Online:

10 May 2020

\begin{abstract}
The Self-Help Group model is over two decades old and has proven its efficacy in tackling rural poverty through self-help and empowerment. The SHGs helped organize millions of rural women into communities so helped them to earn and responded to their credit needs. However, given the SHG approach's positive outcomes, there are many problems and constraints that conflict with the SHGs. The present study was carried out in Ahmedabad district of Gujarat state during the year 2018-19 with a sample size of 120 from 12 SHGs to define the constraints faced and suggestions offered by the members of SHGs. The major constraints faced by the members of SHG were lack of commitment among SHG members followed by lack of education and lack of management skills. Among the suggestions majority of the members offered more income - generating skills training should be organized for the members, women beneficiaries should be provided with adequate financing and subsidies and the members should arrive in time to attend meetings.
\end{abstract}

\section{Introduction}

The concept of the self-help groups (SHGs) stands to underline the principle "for the people, by the people, and of the people". Self-help group is a small economically homogeneous and affinity group of rural poor women which voluntarily agree to contribute to a common fund to be lend to its members as per the decision of the group which works for groups solidarity, self and group awareness, social and economic empowerment in the way of democratic functioning. The group-based approach not only enables the poor to accumulate capital by -way of small savings but also help them to have access to formal credit facilities (Shylendra, 1998).

These groups by way of joint liability enable the poor to overcome the problem of collateral security and thus free them from the clutches of moneylenders (Stigliz, 1993). 
The empowerment of women through selfhelp groups would lead to benefits not only to the individual women and women groups but also for the family and community as a whole through collective action for development. These groups have a common perception of need and an impulse towards collective action. Empowering women is not just for meeting their economic needs but also throw on more holistic social development. The constraints were defined as the difficulties faced by the group members of the SHGs while carryout the activities of SHG. The suggestion is an idea or plan put forward for the consideration. It may be something that implies or indicates a certain fact or situation.

The suggestions given by the respondents were helpful in improve the effectiveness and sustainability of self- help groups. In this context, the present paper aims to highlight the constraints faced by women members of self-help groups (SHGs) and suggestions provided by members in carrying out SHG activities in Gujarat State's Ahmedabad district.

\section{Materials and Methods}

The study was conducted in Ahmedabad district of Gujarat state. Ahmedabad district comprises of nine talukas out of nine talukas, four talukas viz. Daskroi, Dholka, Viramgam and Bavala having higher number of SHGs were selected. From each selected taluka, three SHGs were selected randomly and ten members from each selected SHGs were selected randomly. Thus, total 120 SHGs members were selected randomly from those four talukas.

For collection of data regarding the constraints were obtained through asking for the constraints they faced. On the basis of the responses from the respondents for each of these constraints total score and mean scores of respondents was worked out and rank was given from higher mean scores to lower mean scores. The suggestions given by the respondents were collected to improve the effectiveness and sustainability of self- help groups. The suggestions offered by the members are arranged in descending order of their frequency and per cent.

\section{Results and Discussion}

\section{Constraints faced by members of SHGs}

The information regarding the constraints faced by the members of the Self-Help Groups are presented in Table 1.

The data in the Table 1 revealed that lack of commitment among SHG members ranked first with mean score of 78.33 followed by lack of education (mean score of 72.08), lack of management skills (mean score of 68.75), lack of knowledge about local condition and opportunities (mean score of 52.92), lack of experience (mean score of 35.42), lack of awareness of marketing strategies (mean score of 28.33), lack of risk-taking ability (mean score of 25.83), lack of confidence (mean score of 25.00), lack of discipline (mean score of 24.58), lack of spirit of competition (mean score of 18.33) and family responsibility (mean score of 15.83).The present finding gets support from the findings reported by Bhagyasree (2014) and Bhatt (2010).

\section{Suggestions offered by the members for their sustainability}

The information regarding the suggestions offered by the members of the Self-Help Groups are presented in Table 1.

It could be vividly seen from the Table 2 that more income - generating skills training should be organized for the members ranked 
first with 65.83 per cent followed by women beneficiaries should be provided with adequate financing and subsidies (60.00 per cent), members should arrive in time to attend meetings (58.33 per cent), cooperation between members is necessary (54.17 per cent), literacy for women must be promoted (52.50 per cent), maintain the register regularly (48.33 per cent), providing opportunities for women in business (45.00 per cent), community hall for SHGs (35.83 per cent), for marketing, long - distance and fast transport facilities should be made easily available (34.17 per cent), rotation wise responsibility must be made mandatory (30.83 per cent). The present finding gets support from the findings reported by Bhagyasree (2014).

Table.1 Constraints faced by respondents in SHGs

\begin{tabular}{|c|l|c|c|c|}
\hline $\begin{array}{c}\text { Sr. } \\
\text { No. }\end{array}$ & \multicolumn{1}{|c|}{ Constraints } & $\begin{array}{c}\text { Total } \\
\text { Score }\end{array}$ & $\begin{array}{c}\text { Mean } \\
\text { Score }\end{array}$ & Rank \\
\hline $\mathbf{1}$ & Lack of commitment among SHG members & 188 & 78.33 & I \\
\hline $\mathbf{2}$ & Lack of education & 173 & 72.08 & II \\
\hline $\mathbf{3}$ & Lack of management skills & 165 & 68.75 & III \\
\hline $\mathbf{4}$ & Lack of knowledge about local condition and opportunities & 127 & 52.92 & IV \\
\hline $\mathbf{5}$ & Lack of experience & 85 & 35.42 & V \\
\hline $\mathbf{6}$ & Lack of awareness of marketing strategies & 68 & 28.33 & VI \\
\hline $\mathbf{7}$ & Lack of risk-taking ability & 62 & 25.83 & VII \\
\hline $\mathbf{8}$ & Lack of confidence & 60 & 25.00 & VIII \\
\hline $\mathbf{9}$ & Lack of discipline & 59 & 24.58 & IX \\
\hline $\mathbf{1 0}$ & Lack of spirit of competition & 44 & 18.33 & $\mathbf{X}$ \\
\hline $\mathbf{1 1}$ & Family responsibility & 38 & 15.83 & $\mathbf{X I}$ \\
\hline
\end{tabular}

Table.2 Suggestions offered by the members of SHGs

\begin{tabular}{|c|l|c|c|c|}
\hline $\begin{array}{c}\text { Sr. } \\
\text { No. }\end{array}$ & \multicolumn{1}{|c|}{ Suggestions } & Frequency & $\begin{array}{c}\text { Per } \\
\text { cent }\end{array}$ & Rank \\
\hline $\mathbf{1}$ & $\begin{array}{l}\text { More income - generating skills training should be organized for } \\
\text { the members }\end{array}$ & 79 & 65.83 & I \\
\hline $\mathbf{2}$ & $\begin{array}{l}\text { Women beneficiaries should be provided with adequate financing } \\
\text { and subsidies }\end{array}$ & 72 & & \\
\hline $\mathbf{3}$ & Members should arrive in time to attend meetings & 70 & 58.33 & III \\
\hline $\mathbf{4}$ & Cooperation between members is necessary & 65 & 54.17 & IV \\
\hline $\mathbf{5}$ & Literacy for women must be promoted & 63 & 52.50 & V \\
\hline $\mathbf{6}$ & Maintain the register regularly & 58 & 48.33 & VI \\
\hline $\mathbf{7}$ & Providing opportunities for women in business & 54 & 45.00 & VII \\
\hline $\mathbf{8}$ & Community hall for SHGs & 43 & 35.83 & VIII \\
\hline $\mathbf{9}$ & $\begin{array}{l}\text { For marketing, long - distance and fast transport facilities should } \\
\text { be made easily available }\end{array}$ & 41 & 34.17 & IX \\
\hline $\mathbf{1 0}$ & Rotation wise responsibility must be made mandatory & 37 & 30.83 & $\mathbf{X}$ \\
\hline
\end{tabular}

In conclusion the major constraints faced by the members of SHG were lack of commitment among SHG members followed by lack of education and lack of management 
skills. Among the suggestions majority of the members offered more income - generating skills training should be organized for the members, women beneficiaries should be provided with adequate financing and subsidies and the members should arrive in time to attend meetings.

\section{References}

Bhagyasree P. A study on capacity building and empowerment of Self-Help Groups in Thane district of Maharashtra (Master's thesis, Acharya
N. G. Ranga Agricultural University, Hyderabad). 2014.

Bhatt MR. Group dynamics in tribal women Self Help Groups of Vansda taluka in Gujarat (Master's thesis, Gujarat Agricultural University, Anand). 2010.

Shylendra HS. Promoting Women's Self Groups: Lessons from an action, Research project of IRMA, Gujarat. 1998.

Stiglitz J. Peer Monitoring and Credit Markets, World Bank Economic Review. 1993; 4(3); 351-366.

\section{How to cite this article:}

Chethan Patil, N. D., J. K. Patel, Naveen Kumar Gattupalli, Rahul Dundesh Bellagi and Manunayaka, G. 2020. Constraints Faced and Suggestions Offered by Women Self-Help Groups of Ahmedabad District, Gujarat in Carryout the SHG Activities. Int.J.Curr.Microbiol.App.Sci. 9(05): 3399-3402.

doi: https://doi.org/10.20546/ijcmas.2020.905.404 